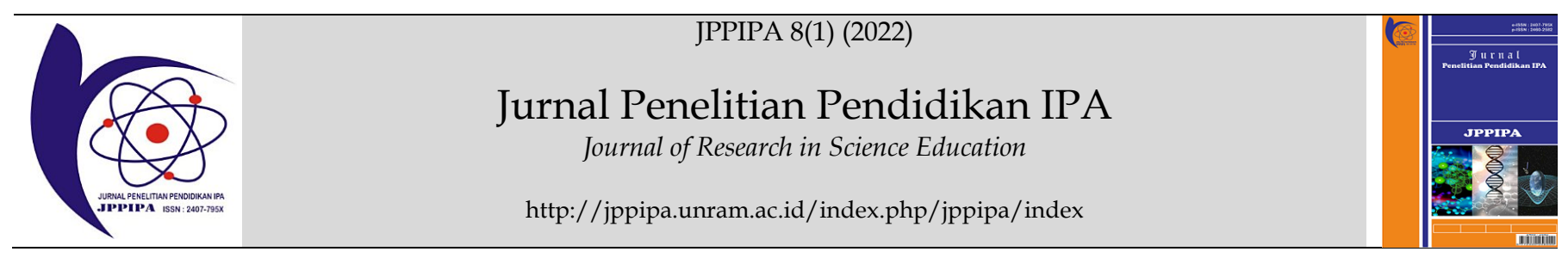

\title{
Analysis of Student Readiness in E-Learning-Based Ecological Learning
}

\author{
Irma Suryani ${ }^{1 *}$, Hasanuddin², Ismul Huda², Samingan², Abdullah² \\ ${ }^{1}$ Biology Education Master Program, Faculty of Teacher Training and Education, Universitas Syiah Kuala, Banda Aceh, Indonesia \\ ${ }^{2}$ Biology Education Study Program, Faculty of Teacher Training and Education, Universitas Syiah Kuala, Banda Aceh, Indonesia
}

\section{DOI: $\underline{10.29303 / \text { ippipa.v8i1.1226 }}$}

\section{Article Info}

Received: December 9, 2021

Revised: January 1, 2022

Accepted: January 23, 2022

Published: January 31, 2022

\begin{abstract}
In the 21st century, learning does not have to be in the real class. In this condition, teachers and students must be able to communicate and adapt to the development of information technology (IT). It is expected that teachers and students must be able to master the use of IT or the internet in e-learning. The purpose of this study was to determine the readiness of students in e-learning-based ecological learning. This approach is a quantitative approach with the type of research being descriptive. The method and design of survey research. The sample of this research is the total population of 340 students. The research instrument is a closing questionnaire, which is the result of adaptation from Tuntirojanawong research. In this study, the data collection was a questionnaire through the website: Aceh Online Learning System: (SpadaAceh). The statistics used for the analysis of the questionnaire data are mean and standard deviation. The results of the study on the student readiness variable include 5 (five) indicators namely technology access (mean 3.52), technology skills (mean 3.51), learning ability (mean 3.65), time management skills (mean 3.51), and learning motivation (mean 3.51). The five indicators fall into the category "Ready but need a few improvements". It can be concluded that readiness students through technology access, technology skills, learning abilities, time management skills, and learning motivation are ready but needs a few improvements.
\end{abstract}

Keywords: Analysis; Student readiness; E-learning based ecology learning

Citation: Suryani, I., Hasanuddin, H., Huda, I., Samingan, S., \& Abdullah, A. (2022). Analysis of Student Readiness in ELearning-Based Ecological Learning. Jurnal Penelitian Pendidikan IPA, 8(1), 356-361. https://doi.org/10.29303/jppipa.v8i1.1226

\section{Introduction}

So far, biology learning is carried out in the classroom by listening and taking notes from the teacher's explanation. This learning tends to be textual and emphasizes the completion of the subject matter. Learning materials that have relatively more topics of discussion while less time is available. This resulted in students only memorizing the subject matter given by the teacher. This raises the perception that biology is a rote lesson and there are too many theories so that students have difficulty understanding the subject matter (Kaya \& Gurbuz, 2002). Biology subject matter is difficult for students to understand (Çimer, 2012). One of the subject matters that have many theories and is difficult for students to understand its ecology. Ecology is a science that studies the reciprocal relationship between organisms and other organisms or studies the reciprocal relationship between groups of organisms and their environment. The above conditions should not happen again in the 21st century. In this century, learning does not have to be in real class but can be done through a digital system.

The digital era is a learning process that integrates Information and Communication Technology (ICT) into all subjects (Kristiawan, 2020). Several challenges affect the implementation of ICT in schools, for example, lack of space, resources, maintenance, lack of ICT skills, and lack of clear ICT policies (Albugami \& Ahmed, 2015). In this era, teachers and students must be able to 
communicate and adapt to the development of information technology (IT). It is expected that teachers and students must be able to master the use of IT or the internet in e-learning.

E-learning is also known as online learning. Elearning is a learning process using the internet which is supported by tools in the form of the latest technology. These technologies include computers, laptops, smartphones, and Android. E-learning is a learning process that integrates various forms of internet-based technology (Sabah, 2013). E-learning can be accessed anytime and anywhere students are (Gulbahar \& Guven, 2008). E-learning is distance learning using computer and internet technology (Simpson, 2001). There are several factors to distance learning such as attention, motivation, emotional aspects, and readiness of learners to e-learning (Tuntirojanawong, 2013). E-learning can increase their motivation, interest, and involvement in the learning process (Pavel et al., 2015). This condition can give students confidence. Students' e-learning experiences can raise their confidence in e-learning (Fogerson, 2005). This learning requires good preparation.

Readiness is a person's condition to be ready to respond in a certain way to certain situations (Slameto, 2013). Readiness in implementing e-learning to be successful (Aydin \& Tasci, 2005). To achieve good learning outcomes, one must have good readiness as well (Hung et al., 2010). Therefore, readiness is needed so that learning can be carried out properly. The process of e-learning required readiness for students (So \& Swatman, 2006). Readiness Learners are ready to respond to the e-learning process they face in their way. This readiness makes it easier for students to accept and understand the material presented by the teacher. Thus, ecological learning can be combined with various technologies and applications that are connected to the internet. This is so that learning ecology through elearning can be done in a more interesting, fun, modern, and sophisticated way by preparing students. The purpose of this study was to determine the readiness of students in e-learning-based ecological learning.

\section{Method}

This research was conducted at MAN 1 Banda Aceh from May to July 2021. This research approach is a quantitative approach with a descriptive type of research. Methods and research design survey methods. A survey method in which data is only obtained/collected through the "Spada Aceh" web which can be accessed by students within a certain period, starting from the learning process, then working on questions to filling out questionnaires. The population in this study were all students of class $X$ MAN 1 Banda Aceh, totaling 340 students. The sample in this study were all respondents in the population who took biology lessons. Sampling is done by total sampling. Research parameters the parameters observed in this study (Tuntirojanawong, 2013) are students' readiness through technology access, technology skills, learning abilities, time management skills, and motivation in online ecology learning.

The research instrument is a closing questionnaire which is the result of adaptation from previous research (Tuntirojanawong, 2013). The questionnaire aims to see the readiness of students. Students' readiness to master five aspects of technology: access to technology, skills, study skills, time management, and motivation. Of the five aspects, as many as 25 items are measured by a Likert scale of 5 alternative answer choices.

Table 1 Student Readiness Score

\begin{tabular}{ll}
\hline Alternative Answer & Likert Scale \\
\hline Strongly Agree & 5 \\
Agree & 4 \\
Neutral & 3 \\
Disagree & 2 \\
Strongly Disagree & 1 \\
\hline
\end{tabular}

Data collection in this study was a questionnaire through the Aceh Spada website with the link http://spada2.aceh.web.id. Questionnaire through the Website Spada Aceh can be seen in Figure 1

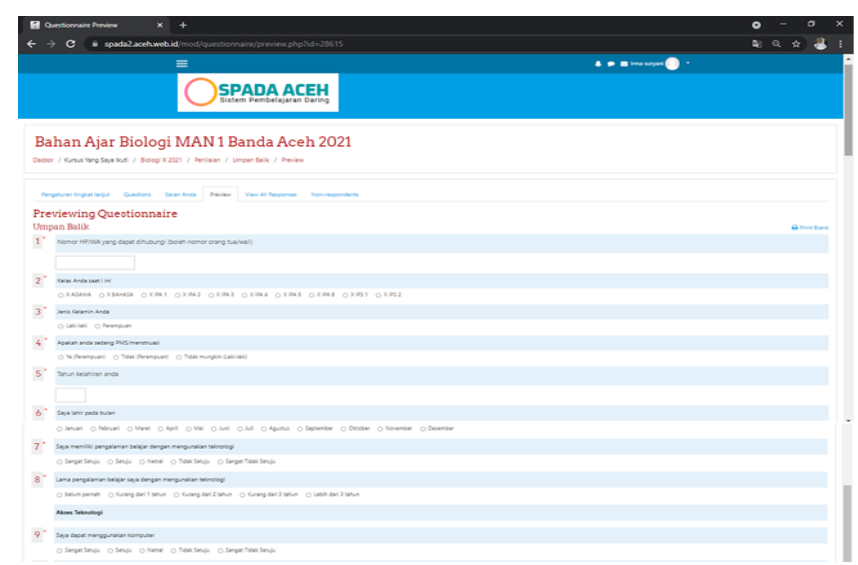

Figure 1. Questionnaire via Website "Spada Aceh"

The data were analyzed using descriptive statistics to provide an overview of the student readiness variables. Student readiness variables can be seen in Table 2.

Table 2. Variables of Student Readiness

\begin{tabular}{lll}
\hline Indicator & Statement/ Question Items & Total \\
\hline Technology Access & $1,2,3,4,5$ & 5 \\
$\begin{array}{l}\text { Technological } \\
\text { Capability }\end{array}$ & $6,7,8,9,10$ & 5 \\
$\begin{array}{l}\text { Technological } \\
\text { Capability }\end{array}$ & $11,12,13,14,15$ & 5 \\
$\begin{array}{l}\text { Time Management } \\
\text { Skills }\end{array}$ & $16,17,18,19,10$ & \multicolumn{2}{|c}{5} \\
Motivation & $21,22,23,24,25$ & 5 \\
\hline
\end{tabular}


The statistics used for the analysis of the questionnaire data are: mean and SD. Furthermore, by looking at the level of readiness of participants, it can be seen in the Figure and Table below:

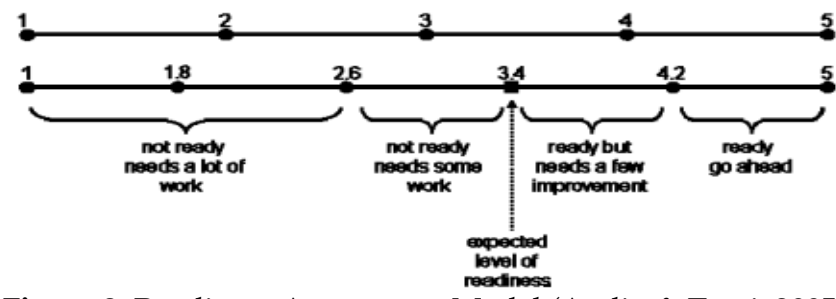

Figure 2. Readiness Assessment Model (Aydin \& Tasci, 2005)

Table 3. Readiness Level

\begin{tabular}{ll}
\hline Interval & category \\
\hline $1<\bar{X} \leq 2.6$ & not ready needs a lot of work \\
$2.6<\bar{X} \leq 3.4$ & not ready needs some work \\
$3.4<\bar{X} \leq 4.2$ & ready but needs a few improvements \\
$4.2<\bar{X} \leq 5$ & ready go-ahead \\
\hline
\end{tabular}

\section{Result and Discussion}

The mechanism for implementing e-learning-based ecological learning at MAN 1 Banda Aceh on 31 May 19 July 2021. This study uses the website Sistem
Pembelajaran Daring Aceh (Spada Aceh) at the link http://spada2.aceh.web.id or it could be with the class address on the link http://gg.gg/biomanbna. Then log in to your account to start the e-learning process.

The learning process is carried out by students by observing ecology lessons in pdf form as reading material and also videos. The next video has been uploaded to Youtube. Youtube can be accessed and studied by students repeatedly anywhere and anytime (Rahmatika et al., 2021). Learners can repeatedly watch 2 learning videos via the link:

https://www.youtube.com/watch?v=NRuN1AmjEZE in the ecology lesson for the first teaching material and https://www.youtube.com/watch?v=z08Lr22MfLM for the second teaching material.

After students have finished observing the teaching materials, it is followed by an exam containing ten questions that are in accordance with the teaching materials. Then the students clicked on the feedback to fill out the Questionnaire. The questionnaire is to see the readiness of students in e-learning-based ecological learning.

Student readiness variables include five indicators are technology access, learning ability, time management skills, and learning motivation (Tuntirojanawong, 2013). The results of the questionnaire can be seen in Table 4 .

Table 4. Technology Access

\begin{tabular}{|c|c|c|c|c|}
\hline No & Statement & $\mathrm{M}$ & SD & Category \\
\hline 1 & I can use the computer every day & 4.00 & 0.58 & Ready but needs a few improvements \\
\hline 2 & $\begin{array}{l}\text { I can connect between my computer and the internet } \\
\text { (wifi) at home }\end{array}$ & 3.70 & 0.71 & Ready but needs a few improvements \\
\hline 3 & I have anti-virus on my computer & 3.16 & 1.02 & Not ready needs some work \\
\hline 4 & $\begin{array}{l}\text { I can install a computer with some required } \\
\text { applications/software }\end{array}$ & 3.34 & 0.83 & Ready but needs a few improvements \\
\hline \multirow[t]{2}{*}{5} & $\begin{array}{l}\text { I can connect between computers and the internet (wifi) } \\
\text { at school }\end{array}$ & 3.38 & 0.72 & Not ready needs some work \\
\hline & Total & $; .52$ & 0.77 & Ready but needs a few improvements \\
\hline
\end{tabular}

Based on the table above, it can be seen that the mean of statement number 1 and number 2 is in the category of "ready but needs improvement". While statements number 3; numbers 4 and numbers 5 are included in the category of "not ready needs some work". Thus, the mean of technology access is 3.51 which means students are "ready but need some improvement". Furthermore, to find out the level of readiness of students towards technology skills, it can be seen in Table 5.

Table 5. Technological Skills

\begin{tabular}{lllll}
\hline No & Statement & M & SD & Category \\
\hline 6 & $\begin{array}{l}\text { I can save and open documents from my hard } \\
\text { disk or other storage }\end{array}$ & 3.84 & 0.65 & Ready but needs a few improvements \\
7 & $\begin{array}{l}\text { I can navigate Web pages. (go to next, or previous } \\
\text { page) }\end{array}$ & 3.66 & 0.68 & Ready but needs a few improvements \\
8 & $\begin{array}{l}\text { I can send and receive emails. } \\
\text { I can solve common errors when using the } \\
\begin{array}{l}\text { internet such as page not found or connection } \\
\text { timed out. }\end{array}\end{array}$ & 3.69 & 0.78 & Ready but needs a few improvements \\
& & 0.91 & Not ready needs some work \\
\hline
\end{tabular}




\begin{tabular}{lllll}
\hline No & Statement & M & SD & Category \\
\hline 10 & $\begin{array}{l}\text { I can use advanced internet skills, such as using } \\
\text { search engines, identifying and downloading } \\
\text { appropriate files, and installing or updating } \\
\begin{array}{l}\text { applications. } \\
\text { Total }\end{array}\end{array}$ & 3.34 & 0.81 & Ready but needs a few improvements \\
& 3.51 & 0.77 & Ready but needs a few improvements \\
\hline
\end{tabular}

Based on the table above, it can be seen that the mean of statement number 6 , number 7 , and number 8 is in the category of "ready but needs improvement". While statements number 9 and number 10 are included in the category of "not ready needs some work". Thus, the mean of technology skills is 3.51 which means students are "ready but need some improvement". Furthermore, to find out the level of readiness of students towards learning abilities, it can be seen in Table 6 .

Table 6. Learning Abilities

\begin{tabular}{|c|c|c|c|c|}
\hline No & Statement & $\mathrm{M}$ & SD & Category \\
\hline 11 & $\begin{array}{l}\text { I can follow a structured approach to finding solutions to } \\
\text { problems. }\end{array}$ & 3.76 & 0.59 & Ready but needs a few improvements \\
\hline 12 & $\begin{array}{l}\text { I can communicate effectively with other students using } \\
\text { online/online technology }\end{array}$ & 3.81 & 0.79 & Ready but needs a few improvements \\
\hline 13 & I can express my thoughts and ideas in writing. & 3.97 & 0.67 & Ready but needs a few improvements \\
\hline 14 & $\begin{array}{l}\text { I can learn new technologies; I don't procrastinate or avoid } \\
\text { them. }\end{array}$ & 3.46 & 0.67 & Ready but needs a few improvements \\
\hline \multirow[t]{2}{*}{15} & $\begin{array}{l}\text { I feel comfortable doing academic work independently and } \\
\text { without regular face-to-face interaction with teachers. }\end{array}$ & 3.23 & 0.85 & Not ready needs some work \\
\hline & Total & 3.65 & 0.71 & Ready but needs a few improvements \\
\hline
\end{tabular}

Based on the table above, it can be seen that the mean of statement number 11; number 12; number 13; number 14 is in the category of "ready but needs improvement" While the statement item number 15 are included in the category of "not ready needs some work". Thus, the mean of learning ability is 3.65 which means students are "ready but need some improvement". Furthermore, to find out the level of readiness of students towards time management skills, it can be seen in Table 7 .

Table 7. Time Management Skills

\begin{tabular}{lllll}
\hline No & Statement & M & SD & Category \\
\hline 16 & I can schedule a time to provide timely responses to other & 3.66 & 0.71 & Ready but needs a few improvements \\
& students or teachers & & & \\
17 & I can control my urge to procrastinate on important tasks. & 3.49 & 0.76 & Ready but needs a few improvements \\
18 & can complete the previous task. & 3.56 & 0.71 & Ready but needs a few improvements \\
19 & I can sacrifice my time to complete assignments and read. & 3.40 & 0.75 & Ready but needs a few improvements \\
20 & I have the self-discipline to log in and follow e-learning. & 3.45 & 0.69 & Ready but needs a few improvements \\
& Total & 3.51 & 0.72 & Ready but needs a few improvements \\
\hline
\end{tabular}

Based on the table above, it can be seen that the mean of statement number 16; number 17; number 18; number 19, and number 20 is in the category of "ready but needs improvement". Thus, the mean of time management skills is 3.51 which means students are "ready but need some improvement". Furthermore, to find out the level of readiness of students towards learning motivation, it can be seen in Tabel 8 .

Table 8. Learning Motivation

\begin{tabular}{|c|c|c|c|c|}
\hline $\mathrm{No}$ & Statement & $\mathrm{M}$ & SD & Category \\
\hline$\overline{21}$ & $\begin{array}{l}\text { I will be able to finish my study even when there is internet } \\
\text { network interruption / not online. }\end{array}$ & 3.25 & 0.78 & Not ready needs some work \\
\hline 22 & I can set goals and objectives for studying & 3.83 & 0.61 & Ready but needs a few improvements. \\
\hline 23 & $\begin{array}{l}\text { I consider flexible time an important driving factor in e- } \\
\text { learning }\end{array}$ & 3.54 & 0.77 & Ready but needs a few improvements. \\
\hline 24 & I enjoy interesting and challenging learning & 3.71 & 0.68 & Ready but needs a few improvements. \\
\hline \multirow[t]{2}{*}{25} & $\begin{array}{l}\text { I stay motivated even though the teacher is not online all the } \\
\text { time }\end{array}$ & 3.24 & 0.88 & Not ready needs some work \\
\hline & Total & 3.51 & 0.74 & Ready but needs a few improvements. \\
\hline
\end{tabular}


Based on Table 8 , it can be seen that the mean of statement number 22; number 23; and the number 24 is in the category of "ready but needs improvement". While the numbers 21 and 25 are included in the category of "not ready needs some work ". Thus, the mean of learning motivation is 3.51 which means students are "ready but need some improvement". Furthermore, the results of the calculation of student readiness indicators can be seen in Figure 2.

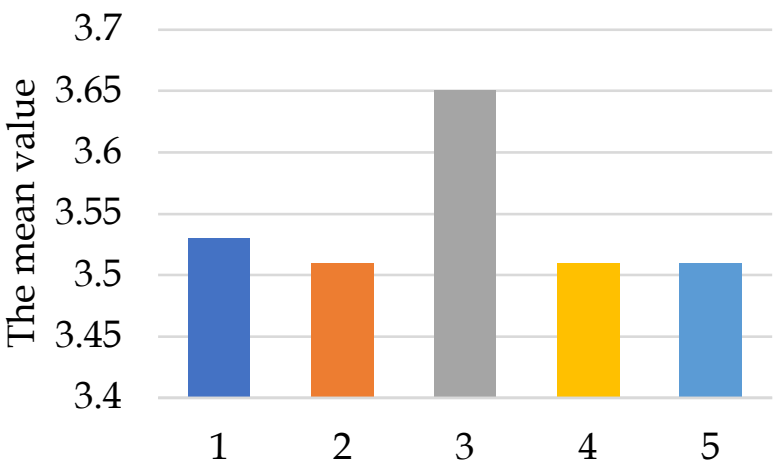

Figure 2. Indicators of Student Readiness

Researchers use five indicators of student readiness are technology access, technology skills, learning ability, time management skills and motivation are in the ready category ready but need a few improvements. The results of the study stated that overall e-learning readiness was ready but needs a few improvements, especially in the field of human resources, to successfully implement e-learning (Aydin $\&$ Tasci, 2005). The results of other studies show that overall e-learning readiness in the ready access and technology skills categories has the highest average score (Tuntirjanawong, 2013). In addition, the results of the study state that (Coopasami et al., 2017) e-learning can be used in education, the readiness of technology and equipment requires attention before being implemented effectively in institutions.

\section{Conclusion}

The variable of student readiness includes five indicators, namely access to technology with a value the mean is 3.52 including the category "ready but needs a few improvements", technology skills with a value the mean is 3.51 including the category "ready but needs a few improvements", learning ability with a value the mean is 3.65 including the category "ready but needs a few improvements", time management skills with a value the mean is 3.5 including the category "ready but needs a few improvements" and learning motivation with a value the mean is 3.51 including the category "ready but needs a few improvements". Thus, the readiness of students in e-learning-based ecological learning is ready but needs a few improvements.

\section{Acknowledgments}

I thank the principal who has allowed me to do this research, I also thank the biology teachers and the teacher council, curriculum, academics, all staff, and students of MAN 1 Banda Aceh who has participated in this research.

\section{References}

Aydin, C. H., \& Tasci, D. (2005). Measuring readiness for e-learning: Reflections from an emerging country. Educational Technology and Society, 8(4), 244-257.

Çimer, A. (2012). What Makes Biology Learning Difficult and Effective: Students' Views. Educational Research and Reviews, 7(3), 61-71. https://doi.org/10.5897/ERR11.205

Coopasami, M., Knight, S., \& Pete, M. (2017). e-Learning readiness amongst nursing students at the Durban University of Technology. Health SA Gesondheid, 22, 300-306. https:// doi.org/10.1016/j.hsag.2017.04.003

Fogerson, D. L. (2005). Readiness Factors Contributing to Participant Satisfaction in Online Higher Education Courses. In Doctoral Dissertations.The University of Tennessee. Retrieved from https://trace.tennessee.edu/utk_graddiss/1952

Gulbahar, Y., \& Guven, I. (2008). A survey on ICT usage and the perceptions of social studies teachers in Turkey. Educational Technology and Society, 11(3), 37-51.

Hung, M. L., Chou, C., Chen, C. H., \& Own, Z. Y. (2010). Learner readiness for online learning: Scale development and student perceptions. Computers and Education. https://doi.org/10.1016/j.compedu.2010.05.004

Kaya, V. E., \& Gurbuz, H. (2002). The Views Of The High Schools And Vocational High Schools Students On The Problems Of Biology Teaching. Journal of Education Faculty, 4(2), 11-21. Retrieved from https://dergipark.org.tr/en/pub/erziefd/issue/5 990/79724

Kristiawan, M. (2020). A Model for Upgrading Teachers' Competence on Operating Computer as Assistant of Instruction. Global Journal of Human-Social Science., $\quad 14(5), \quad 42-55$. https://doi.org/10.31219/osf.io/m6wgn

Pavel, A.-P., Fruth, A., \& Neacsu, M.-N. (2015). ICT and E-Learning - Catalysts for Innovation and Quality in Higher Education. Procedia Economics and Finance, 23, 701-711. https://doi.org/10.1016/s2212-5671(15)00409-8

Rahmatika, Yusuf, M., \& Agung, L. (2021). The 
Effectiveness of Youtube as an Online Learning Media. Journal of Education Technology, 5(1), 152-158.

Sabah, N. M. (2013). Students' attitude and motivation towards e-learning. In Proceedings of The First International Conference on Applied Sciences (ICAS) (May. 1-6).

Simpson, O. (2001). Supporting Students in Online, Open, and Distance Learning. London: Kogan.

Slameto. (2013). Belajar dan Faktor-Faktor yang Mempengaruhi. Jakarta: Rineka Cipta.

So, T., \& Swatman, P. M. C. (2006). e-Learning readiness of Hong Kong teachers. Hong Kong IT in Education Conference, February, 6-8. Retrieved from http://blog.uny.ac.id/nurhadi/files/2010/08/sw atman-hongkong.pdf

Tuntirojanawong, S. (2013). Students ' Readiness for Elearning: A Case Study of Sukhotai Thammathirat Open University, Thailand. Journal of Learning in Higher Education, 9(1), 59-66. Retrieved from https://eric.ed.gov/?id=EJ1143992 